\title{
EDUCATION OF COMPETENCIES OF ORGANIC PRODUCTION: POSSIBILITIES AND PROBLEMS
}

\author{
Nijolė Jurkšaitienė, Laima Markevičienė \\ Kaunas University of Applied Sciences, Faculty of Landscaping \\ Department of Green Plantations and Agrotechnologies \\ Mokslo Street 2, Mastaiciai, 53313 Lithuania \\ E-mail: nijole.zak@gmail.com, laima.mark@gmail.com
}

\begin{abstract}
Organic farming must seek profitability, social goals and ecological balance. Not only farmers and processors but also consumers are responsible for this, subsequently, education of every segment is very important. In order to modernize technologies of organic farming it is necessary to have qualified and experienced employees for industrial areas as well as for organisation of environmental protection.

The article is trying to assess development of organic farming and to evaluate education of specialists of organic production in Lithuania. Therefore, there are analysed the results of certification of farms, carried out by the public organisation "Ekoagros", and a particular interest is paid to educational establishments which educate specialists of organic production. The article also analyses development of organic farms in Lithuania, presents basic problems and examines possibilities to educate specialists of organic agricultural production.
\end{abstract}

Keywords: ecology, certification, education, organic products.

\section{Introduction}

The European Union's common agricultural policy is more and more aimed at organic farming. It is so, mainly, because this particular farming enables to preserve nature and gives social and economic benefit.

Organic farming (ecological, biological, and bioorganic) is agricultural system based on the set of ecological, social and economic concepts which ensure constant manufacturing of high quality products. What is more, this system sustains natural balance and uses natural resources sustainably. This is the highest form of environmentally friendly farming [2].

Organic farming ensures implementation of basic principles of harmonious development. Firstly, ecological: reduction of pollution created by organic farming, preservation of biological diversity, cultivation of safe food and raw materials. Secondly, economic: usage of local recourses, reduction of energy expenditures and more favourable solutions of economic problems that are faced by farms. Then, social: increase of workplaces in rural areas. Finally, cultural: development of a farmer's spiritual culture and nurturance of Lithuanian ethno culture [3].

Interest in organic farming is determined not only by consumers' interest in food safety but also concern about quality of environment and constant and balanced development of farming. Application of EU and national support for organic production farms induces this way of production in Lithuania. In 1997 the Ministry of Agriculture alongside with the Ministry of Health established public enterprise "Ekoagros" and appointed it to carry out inspection and certification of organic production under the regulations for organic farming. Control and certification of organic production is carried out in accordance with European Union Council Regulation (EC) No. 834/2007, Regulation (EC) No.889/2008 and rules for organic farming. Since 2008 "Ekoagros" has a permission to certify agricultural and food products of exceptional quality, according to the rules of recognition of agricultural and food products of exceptional quality, which were approved on 29 November in 2007 by the Minister's of Agriculture of the Republic of Lithuania order No. 3D-524. Since 2005 certification establishment has been accredited by National Accreditation Bureau of Ministry 
of Environment of the Republic of Lithuania. In January 18 in 2007 the Bureau gave public enterprise "Ekoagros" accreditation to certify, according to the requirements of BS EN 45011:2000 standard, processes of organic production: processes of production of organic plant-growing, husbandry, apiculture, wild vegetation and fishery as well as food of nonanimal and animal origin [5].

In order to modernize technologies of organic farming it is necessary to have qualified and experienced employees not only for administration of environmental protection but also for industrial areas [1]. In Lithuania knowledge of environmental protection is provided to all target groups: for students of universities, pupils of agricultural schools as well as of general secondary schools, listeners of special courses, farmers and teachers (lectures).

Aim: to analyse and to support theoretically possibilities and problems of the education of specialists of organic production in Lithuania.

Research methodology: system and comparative analysis of scientific literature, comparative analysis of statistic data.

\section{Results}

The beginning of organic farming in Lithuania dates back to 1993. In that particular year there were certified 9 farms of organic production (148 ha of soil being used). Lithuanian government began to support organic farming only in 1997, when the fund "Tatula" was established. In 2009 certification establishment "Ekoagros" received 2732 requests to certify organic production. 166 requests were submitted by new applicants. Over 100 farms have been certified in the districts of Biržai, Ukmerge, Raseiniai, Šalčininkai, Trakai, Telšiai and Varèna (Figures 1 and 2).

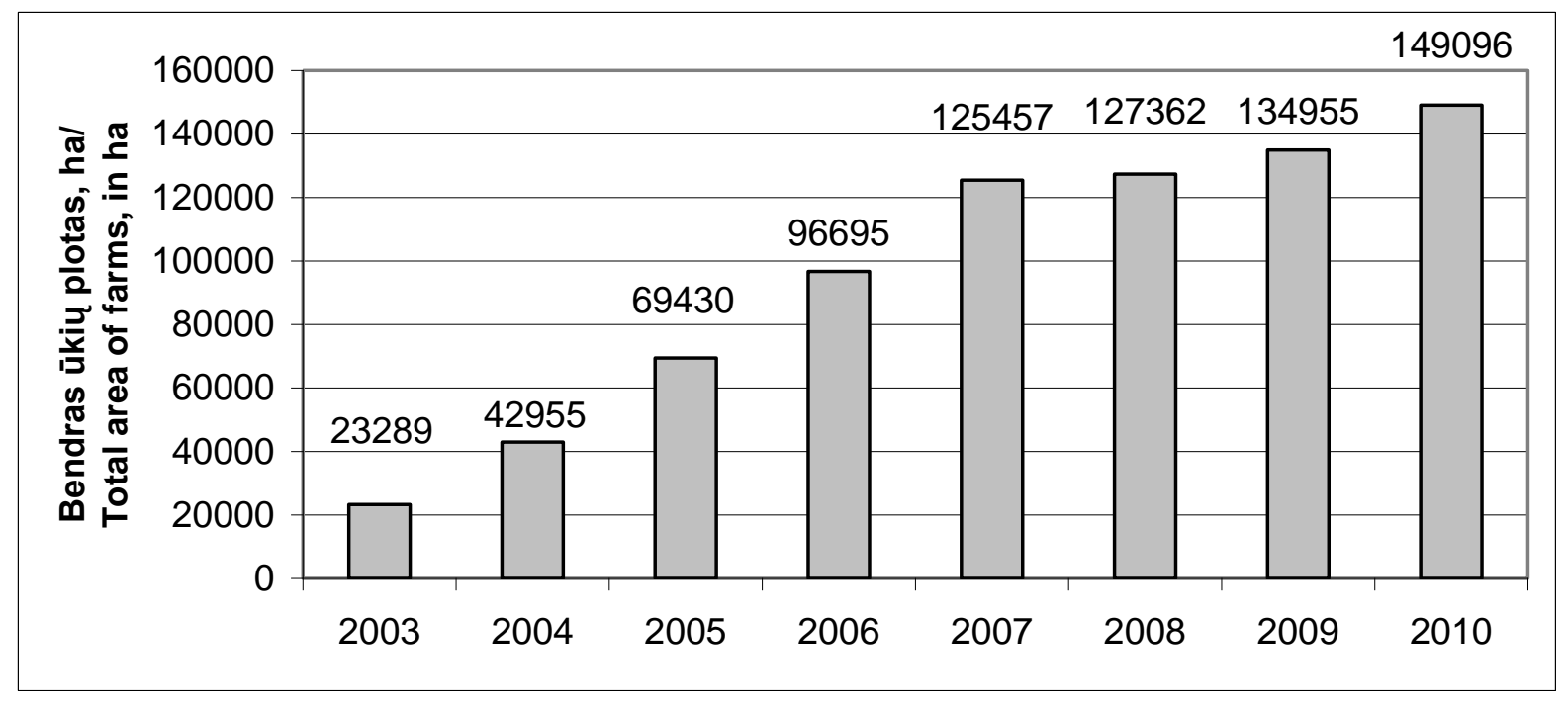

Fig. 1. Area of organic farms certified in Lithuania between the years 2003-2010 [5]

A particular growth of certified organic farms can be seen in the years 2007 (2956) and 2009 (2679). In the receant two years the number of organic farms remained stable, however, there can be traced an increase of 23639 ha in the area of farms (from 125457 ha in 2007 up to 149096 ha in 2010), this is, mainly, due to the fact, that a number of large farms decided to start organic production. Nowadays an avarage organic farm embodies about 41 ha and is, actually, larger than a typical country farmer's farm. In 2009 there were certified 35 farms of apiculture and 20 collectors of wild vegetation bring to the market 400 names of organic, certified products of wild plants (Table 1). 


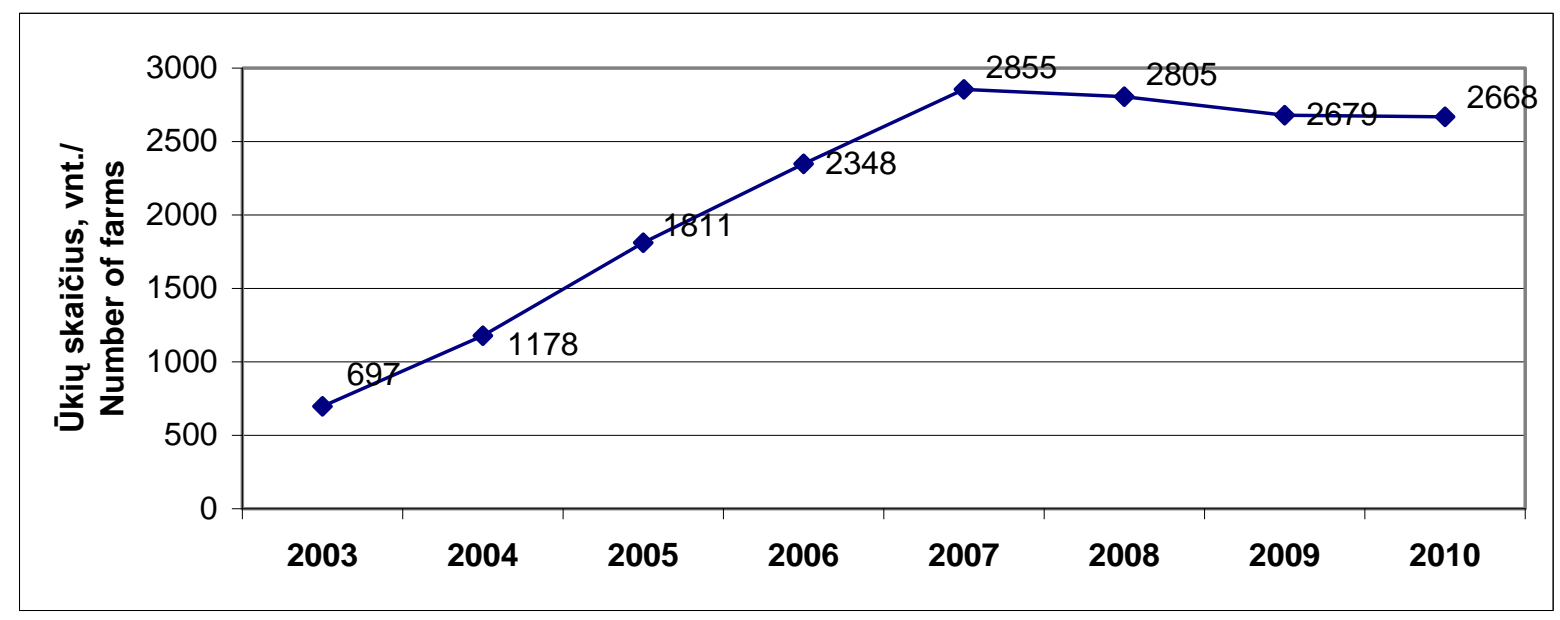

Fig. 2. Number of organic farms certified in Lithuania between the years 2003-2010 [5]

Structure of area of certified crops in Lithuania in 2010
\begin{tabular}{|l|c|}
\hline \multicolumn{1}{|c|}{ Certified areas } & $\begin{array}{c}\text { Part, } \\
\text { percent }\end{array}$ \\
\hline Cereals & $45.72 \%$ \\
\hline Perennial grasses & $20.98 \%$ \\
\hline Legume crops & $12.64 \%$ \\
\hline Grass legume crop mixture & $6.19 \%$ \\
\hline Herbs, aromatic spice plants & $5.01 \%$ \\
\hline Stocked ponds & $3.67 \%$ \\
\hline Berries & $2.68 \%$ \\
\hline Fallows (black and manure) & $1.58 \%$ \\
\hline Gardens & $0.96 \%$ \\
\hline Vegetables (including fodder beet) & $0.32 \%$ \\
\hline Crops not meeting required density & $0.25 \%$ \\
\hline
\end{tabular}

Table 1.

Structure of crops consists of approximately $45.72 \%$ of cereals and $12.64 \%$ of legume crops. In organic husbandry there are grown just 275 pigs and 1500 birds.

In 2007720 husbandry farms were certified. The number of old breeds of farm animals and birds was about 4391. In 2009 there were 817 organic husbandry farms registered in Lithuania. If compared to 2006 the number has increased by $13.5 \%$.

There are more and more large organic husbandry farms. Expansion of certified areas influences augmentation in the growth of organic production. Because of the increase of raw material and society's interest in organic products, involvement of processors have also become bigger. More and more enterprises are becoming interested in the possibilities to process organic products. As the number of growers of organic products is increasing there, naturally, appear more and more food processing enterprises which are able and willing to process or handle organic products in any other way. A demand for organic products is constantly growing in Lithuania.

Because of the increase of raw material and society's interest in organic products, involvement of processors have also become bigger. More and more enterprises are becoming interested in the possibilities to process organic products. In 2009 there were certified 59 farm units processing organic products, which were involved in processing of herbs, milk, meat and corns, production of forages and transportation of organic products as well as engaged in trade activities. In 201071 farm units were certified. 
In the project of Lithuanian Rural Development Programme for 2007-2013 it is presumed that in 2013 the number of organic farms should reach 6000 units and the area of organic farms should expand up to 240000 ha. It is supposed that in the coming years it should make up to $10-15 \%$ of all agricultural farms of our country.

As the development of organic agricultural and food production increases and there is a need to solve the problems that may arise because of this, there is a growing demand for specialists of organic production. In Lithuania it is possible to acquire ecological knowledge:

- while studying at colleges and universities;

- studying at the institutions of vocational training and acquiring qualification of employee of an organic farm;

- after fulfilment of educational programme on the fundamentals of organic farming.

These days it is essential to presuppose the demand of the specialists based on the changes in the labour market. Specialists' competitive competencies must be achieved through active cooperation with employers, renewal of training base and development of educational programmes.

In Lithuania there are 7 educational institutions training specialists of organic production (Table 2).

Table 2.

Educational institutions training specialists of organic production

(Jurkšaitienè, Markevičienè, 2010)

\begin{tabular}{|l|l|l|}
\hline No. & \multicolumn{1}{|c|}{ Educational institution } & \multicolumn{1}{c|}{ Educational programme or field } \\
\hline 1. & Lithuanian University of Agriculture & $\begin{array}{l}\text { Bachelor in Agroecology and environmental } \\
\text { protection } \\
\text { Master in Agroecosystems }\end{array}$ \\
\hline 2. & $\begin{array}{l}\text { Kaunas University of Applied } \\
\text { Sciences }\end{array}$ & Organic production \\
\hline 3. & Marijampole College & Organic agriculture \\
\hline 4. & Utena College & $\begin{array}{l}\text { Agroecology: Organization and development of } \\
\text { organic farm, preparation and realization of organic } \\
\text { products, waste management }\end{array}$ \\
\hline 5. & $\begin{array}{l}\text { Vilnius University of Applied } \\
\text { Sciences }\end{array}$ & $\begin{array}{l}\text { Management of agribusiness (field: trade of organic } \\
\text { products) }\end{array}$ \\
\hline 6. & $\begin{array}{l}\text { Alanta School of Technology and } \\
\text { Business }\end{array}$ & Worker of an organic farm \\
\hline 7. & Joniškis Agricultural School & Worker of an organic farm \\
\hline
\end{tabular}

Specialists of organic production are trained at 4 colleges, 2 vocational schools and at Lithuanian University of Agriculture. In the Department of Plantations and Agrotechnologies in the Faculty of Landscaping at Kaunas University of Applied Sciences there is implementation of educational programme of technologies of agribusiness, with specialization in organic production.

Educational activities are carried out by the Chamber of Agriculture of the Republic of Lithuania and the Ministry of Agriculture of the Republic of Lithuania: informal farmers' trainings, projects, seminars and courses. According to the long term strategy of Lithuanian Agricultural Development till 2015 as well as to the data of 2010 presented by Associated Chambers of Trade, Industry and Handicrafts of Lithuania, Lithuanian Free Market Institute and National Farmers' Union, in the future there will be a great demand for specialists of organic farm. 
While examining geographical position of the educational institutions training specialists of organic production, it became vivid that all those educational institutions are in the districts where the number of organic farms is the biggest (Figure 3).

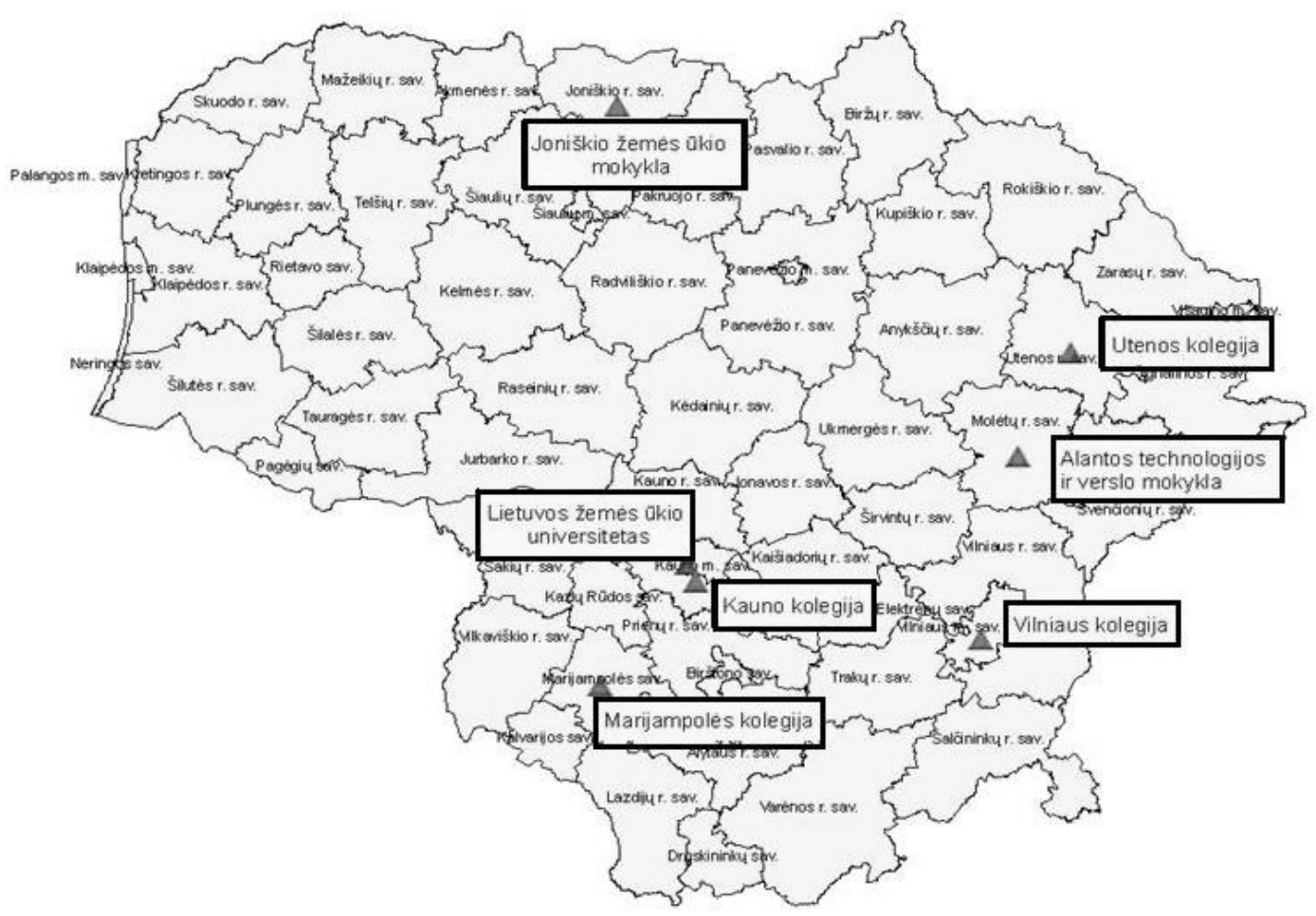

Fig. 3. Places in Lithuania where specialists of organic production are trained

(Jurkšaitienè, Markevičienè, Sikorskytè, 2010)

The Chamber of Agriculture of the Republic of Lithuania, which is situated in Kaunas, with the help of their representatives in all the municipalities, provide a possibility to participate in informal professional farmers' training as indicated in the project "Farmers' informal vocational education under technological programmes" and to attend 24-hours courses of basics of organic farming.

The European Union's common agricultural policy is more and more aimed at organic farming which brings environmental, social and economic benefit. However, there are lots of problems in farms of organic production and it does not look like they are going to disappear:

- uncompleted agricultural reform;

- farmers having organic farms have no right of seniority while leasing state land;

- no law about processing of organic products on a farm is prepared;

- instances of farms that do not follow principles of organic farming;

- growing of seeds of plants appropriate for organic farming is not organized and developed;

- insufficient supply of organic fertilizers, plants security facilities and equipment;

- no sampler organic farm has been established;

- very weak farmers' cooperation;

- promotion of usage of organic products is not good enough;

- sufficient and constant provision of organic products to supermarkets is not ensured;

- there would be a possibility to create more workplaces in rural areas, to expand areas of vegetables, gardens and berries and to increase consumption of such products, unfortunately, these opportunities are not employed. 


\section{Conclusions}

Issue of environmental protection is very vital these days. Importance and influence of organic farming to the development of society is often perceived through the prism of principles of cohesive development. Subsequently, it is vivid that way of organic production creates circumstances suitable to solve economic and social problems as well as those related to protection of environment. In Lithuania organic farming began in 1993. In the period of 20 years there has been acquired some practice and system of certification created. Output of production of organic farms is constantly growing in Lithuania: approximately $60 \%$ a year. Just 9 organic farms were certified in 1993, whereas in 2009 there were received 2732 requests to certify production. In the project of Lithuanian Rural Development Programme for 2007-2013 it is presumed that in 2013 the number of organic farms should reach 6000 units and the area of organic farms should expand up to 240000 ha. It is supposed that in the coming years it should make up to $10-15 \%$ of all agricultural farms of our country.

In order to accelerate development of organic production in Lithuania, the Ministry of Agriculture support farmers' training, education, scientific researches and improve certification system.

Development of organic farming is influenced by a range of various problems. It should be mentioned that young specialists, farmers and inhabitants of rural areas have little motivation to participate in trainings. There are a lot of institutions that propose educational courses in the same places and on similar topics. What is more, participants of the courses have very different level of education; their understanding of technological, economic and legal agricultural issues also diverges.

\section{Summary}

Nowadays competitive economics demands new ideas, modern technology, and constant development of professional competences and, of course, a mature and universal personality. High professional requirements in the labour market entail new methods of development and education of a specialist.

Organic farming differs from other ways of farming as farms of organic production must obey strict rules for organic farming, and products of such farms must have certificate of their origin. Actually, a huge demand in the market was determined by certification and labelling of organic products. Only certified farms and enterprises can trade products which are labelled with a sign of organic products. In Lithuania certification of organic farms is carried out by the public enterprise "Ekoagros".

In Lithuania specialists of organic production are trained in 7 educational establishments. Their geographical position is optimal and they all are in the districts having the biggest number of organic farms.

It is possible to acquire knowledge in organic farming while participating in various courses, trainings, seminars and projects that are organised by the Ministry of Agriculture of the Republic of Lithuania and the Chamber of Agriculture of the Republic of Lithuania.

\section{References}

1. Dalia Marija Brazauskiene. Ekologinių žinių integracija mokymo procese. Prieiga per internetą http://www.bernardinai.lt/straipsnis/2010-01-10-/38205

2. Jurkšaitienè, Nijolè. Ekologinio žemès ūkio pagrindai. mokymo priemonè. Mastaičiai, 2009. p.95. ISBN 978-9955-27-149-9.

3. Lazauskas Petras. Ekologinis žemès ūkis. Akademija. 2008. ISBN 978-9955-865-08-7.

4. Žekonienè, Vanda; ir Daugèlienè, Nijolè; ir Bakutis, Bronius. Moksliniu rekomendaciju taikymo ekologiniame ūkyje pagrindai. Lietuvos žemès ūkio universitetas, 2006, 146 p. ISBN 9955-448-52-0.

5. Vš̃ “Ekoagros”. Ekologinis ūkininkavimas. Prieiga per internetą: http://www.google.lt/search?hl=lt\&source=hp\&q=ekoagros.lt\&aq=1\&aqi=g8\&aql=\&oq=ekoagros 